\title{
Residents' perception toward protected areas - Carska Bara Special Nature Reserve (Vojvodina, Serbia)
}

\author{
Tamara Jojić Glavonjić $\mathrm{A}^{*}$, Jovana Brankov ${ }^{\mathrm{A} B}$, Dragana Miljanović ${ }^{\mathrm{A}}$ \\ Received: September 24, 2018 | Revised: December 21, 2018 | Accepted: December 23, 2018
}

DOI: 10.5937/gp22-18960

\begin{abstract}
The research was carried out in the villages of the buffer zone and the close environment of the Ramsar site "Stari Begej - Carska Bara" Special Nature Reserve, in the Serbian part of Banat. The survey method was used to establish the local population's attitude towards the impact of area protection on their life quality and the degree of cooperation with the managing body. A total of 393 adults were surveyed, which accounted for $5.34 \%$ of the total adult population of the studied area (five villages). In order to provide opinions from all stakeholders, the managing body was also asked to respond to some of the questions. A comparison of the responses revealed a generally low level of dialogue and understanding between the two interested parties. The results indicate some differences in the degree of impact depending on the location of the villages, as well as the occupation of the respondents and their age.
\end{abstract}

Keywords: protected area; Ramsar; managing; attitude towards the impact; Serbia

\section{Introduction}

A number of studies have been conducted on the impact of protection on the life of the local population in Ramsar areas around the world (Tomićević et al., 2010; Karki, 2013; Bennett \& Dearden, 2014; etc.). The study that is the most similar to the research presented in this paper in terms of the subject and tested variables was conducted twenty years ago in northern Greece (Christopoulou \& Tsachalidis, 2004). In 19971998, a team of students from the Technological Educational Institute of Drama surveyed the local population of four Ramsar areas, i.e. 32 settlements in their surroundings. The sample consisted of 1600 questionnaires, 400 per protected area. As a result, it was concluded that the local population, which mostly consisted of farmers, was aware of the boundaries of the protected area, but did not abide to strictly defined restrictions and was not satisfied with the management of the protected area. An increased number of visitors and tourism-related development were desirable, as well as the institutional and financial support from the state. As a result of the research, some guidelines for future development were defined, such as: the development of ecotourism and agrotourism, designing programs or workshops and seminars for the local population, with an emphasis on the importance of preserving wetlands (especially in settlements where the respondents opted for drying out) and participation management that would enable all of the abovementioned requirements (Christopoulou \& Tsachalidis, 2004). The main point of distinction between

A Geographical Institute "Jovan Cvijić", Serbian Academy of Science and Arts, Đure Jakšića 9/III, 11000 Belgrade, Serbia; t.jojic@gi.sanu.ac.rs

B Institute of Sports, Tourism and Service, South Ural State University, Sony Krivoy street 60, 454080 Chelyabinsk, Russia; j.brankov@gi.sanu.ac.rs

* Corresponding author: Tamara Jojić Glavonjić; e-mail: t.jojic@gi.sanu.ac.rs, tel. +381638212505 
ecotourism and other types of sustainable tourism is the fact that it must be seriously planned. It is necessary to devise advertising strategies adjusted to the target group of nature lovers, as well as to train managers, empower locals to provide tourist guidance services and adopt appropriate policies aimed at promoting the sustainable development of local communities. It is particularly important to ensure a wider involvement of the local population in tourism development (starting with the obligation to obtain their consent for tourism development in their villages) through training and assignment of funding aimed at encouraging ecotourism development (Wood, 2002). As far as agrotourism is concerned, the goal is to ensure multiple profits for the local economy, or benefits from multiple segments. Some authors (Petrović et al., 2017) cite the classification of agrotourism subjects established by Sznajder, Przezborska, and Scrimgeour (2009) into four distinct groups: those who directly provide tourists with accommodation and services; those who use agrotourism to sell their products; those who promote their products through agrotourism; and those who support this type of tourism (travel agencies, transport companies, souvenir manufacturers).

Similar research studies have been carried out in Serbia (Stojanović et al., 2011; Drašković, 2013; Pavić et al., 2016), where Ramsar sites are not rare. Ten areas currently have this status, while the Institute for Nature Conservation of Serbia has compiled a list that identifies 68 potential Ramsar sites. However, the main problem is that their protection remains solely in the domain of legal protection.

When defining the research area for this study, we considered the following criteria:

- the proximity of the settlement, namely the location of the settlement in the area close to the protected asset. For this purpose, we consulted Special Purpose Area Spatial Plans, which have been defined for most Ramsar sites, in accordance with the Law on Planning and Construction. Settlements that fall under the protection regime III and the buffer zone were taken into consideration;

- the extent of traditional uses of the protected area's natural resources, such as agriculture, mowing, use of bulrush, grazing, aquaculture; and
- the length of period "under protection", where the period of at least ten years was taken as reference, because it takes some time under protection to see whether the selected management model is efficient. Out of the ten Ramsar sites in Serbia, only has met the defined criteria. This protected area and its population were already subject to a similar research five years ago. The Institute of Economic Sciences from Belgrade, led by Professor Drašković, carried out a survey in 2012 to explore the protected area, namely to evaluate it as a natural capital. The study was prevailingly focused on economic aspects, namely the concept of environmental or green accounting, which is materialized in money. According to this concept, the value of a natural area is observed as a resource and analyzed in the context of profits gained and the amounts to be paid for the damage done to it. When determining the boundaries of the population survey area, Drašković (2013) and his team were guided by the spatial coverage, i.e. the boundaries of the Special Purpose Area Spatial Plan for the Stari Begej - Carska Bara Special Nature Reserve (Official Journal of the Province of Vojvodina, 2009), which encompassed five settlements partly included in the Reserve's buffer zone and close surroundings.

Our survey, conducted in 2017, had the same coverage. The basic hypothesis $\left(\mathrm{H}_{1}\right)$ was: Declaring the Carska Bara Special Nature Reserve has little or no impact on the life and economy of the local population. Hi contained five sub-hypotheses:

1. Hia: The local residents have no benefit from the life in the protected zone or in the immediate surroundings of the Reserve.

2. Hib: The local residents do not suffer any harm caused by living in the protected zone or the immediate vicinity of the Reserve.

3. Hic: The age of the local inhabitants has to do with their decision to stay or leave.

4. Hid: The local residents' education level has an impact on their preference for staying in the place of residence or leaving it.

5. Hie: The location, i.e. the distance of the settlement from the Reserve affects the local residents' perception of the Reserve and its impact on the quality of life.

\section{Methodology}

\section{The study area}

The Carska Bara Special Nature Reserve (the term means "Imperial Pond") is a protected area located in the northern part of Serbia, in the Autonomous Province of Vojvodina, in the Central Banat District, one of the 29 administrative districts in Serbia. It is locat- ed in the territory of the municipality of Zrenjanin, the largest municipality of the Serbian part of Banat, and covers a total area of 4726 ha, including parts of the cadastral municipalities of Belo Blato, Knićanin, Lukino Selo, Perlez and Stajićevo. The Reserve consists of two distinct spatial units - Mužljanski Rit 


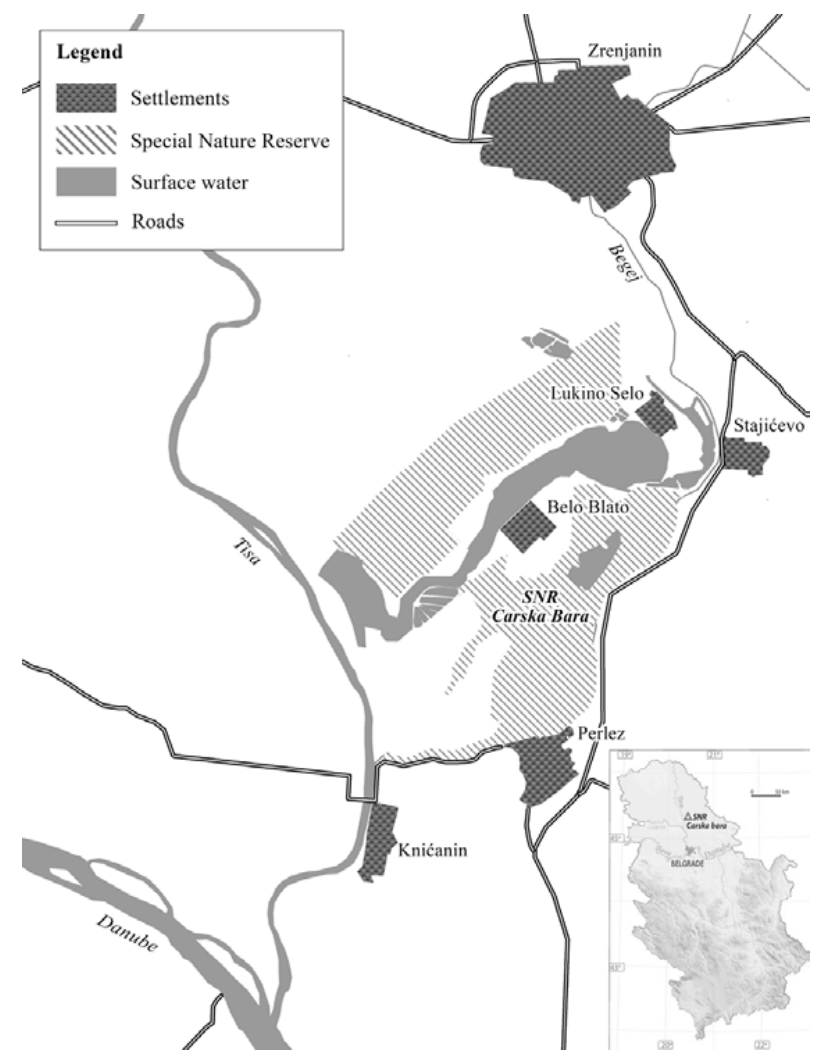

Figure 1. The Reserve with surrounding villages and its location in Serbia

(2062 ha) and Carska Bara (2664 ha) (Official Gazette of the Republic of Serbia 46/2011) (Fig. 1).

The former unit was as early as 1955 a protected part of the reserve called Vojtina Mlaka. In 1986, the regional nature park Stari Begej, including Carska bara, was declared a strict natural reserve, covering an area of 1300 ha. In 1994, the area was declared a special nature reserve named Stari Begej - Carska Bara. It was included in the list of Ramsar areas as Stari Begej Carska Bara Special Nature Reserve in March 1996. ${ }^{1}$

A whole mosaic of various ecosystems (rivers, ponds, lakes, meadows, salt marshes, steppe, forests and plowlands) in the wider area of Stari Begej (Begej branch) and Carska Bara are intersected with channels, embankments and field roads. There are about 500 plant species, 24 species of fish, 11 species of amphibians, five species of reptiles and 50 species of mammals, and the highest value of this IBA, IPA and
Emerald spot are birds, with about 250 species (Ministry of environmental protection and Institute for nature conservation of Serbia, 2007). The managing body is the Ečka Fishing Farm, located in Lukino Selo (Manager).

\section{Interviews}

The research used a survey method. The survey covered only the adult inhabitants of the five villages in the area of the Special Nature Reserve (the Reserve): Belo Blato, Knićanin, Lukino Selo, Perlez and Stajićevo. A total of 393 responses were received, accounting for $5.34 \%$ of the villages' adult population. The respondents were either interviewed or they filled in the questionnaires personally. The questionnaire consisted of 39 questions in total. The first eight questions related to the personal characteristics of the respondents (sex, age, education level, etc.), and the remaining questions were divided into three groups. The first group of questions was related to the use of resources, the second to tourism, and the third to the respondents' attitudes towards the Reserve. The collected data were analyzed using the Statistical Package for Social Sciences (version 13.0). Descriptive statistical methods were used for the analysis of most variables, while the relationships between some variables important for obtaining the required answers were examined using correlation (age and stay/leave preference, education level and stay/leave preference, women and organic production, farmers' opinion on the possibility of earning a decent livelihood from agriculture, i.e. the opinion of tourist workers on the possibility earning a decent livelihood from tourism). Seeking to take into account the opinions of all stakeholders, we also interviewed a representative of the Manager, responsible for environmental protection. The survey for the Manager contained eight questions, identical to those presented to the local residents. The questions were specifically related to the impact of the Reserve on the local population, i.e. the benefit for and damage to which local residents were, or were not, exposed, as well as the relationship among stakeholders. The conclusions about the on-site situation were made based on the comparison of the obtained answers, interviews of stakeholders and visits to the examined settlements.

1 This name was changed in 2011, when it was renamed as the Carska Bara Special Nature Reserve, according to a new regulation (Official Gazette of RS, No. 46/2011). The Ramsar site still has the old name, but it will be renamed, as well. 


\section{Results and discussion}

Due to space constraints, only variables that are significant for the analysis of the on-site situation will be presented in the paper.

It was evident from the conversation with the local population and the representative of the Manager that the Reserve did not have the same impact on all settlements. Therefore, the investigated area was divided into two parts: the area of the SNR buffer zone and the area of the SNR's close environment.

\section{Special Nature Reserve's buffer zone}

In the buffer zone, the villages of Belo Blato and Lukino Selo are located. Both villages have an unfavorable position in the flood plain of the Tisa and Begej rivers, the only protection against which, during high-water periods, are embankments. Belo Blato has an additional disadvantage, which is reflected in a markedly peripheral position in relation to the center of the municipality (Ćurčić, 2004).

In the Reserve's buffer zone, 122 inhabitants were surveyed (Table 1). The average age of the respondents was 42.3 years. The surveyed sample included $52.5 \%$ of men and $47.5 \%$ of women. One-half of the surveyed ture in their current place of residence. It turned out that the education level had no impact on the decision to stay or to leave. Accordingly, in all education categories a preference for staying prevailed $-72.5 \%$ of the respondents with an elementary education, $65.6 \%$ with secondary/grammar-school education, $77.8 \%$ of the respondents with a college/university degree.

Land was the natural resource used by the majority of the respondents $-59 \% ; 12.3 \%$ of the respondents were involved in farming, hunting and fishing, while $26.2 \%$ stated that they used no resources whatsoever. Out of the total share of respondents involved in agriculture (61.2\%), 40.5\% traded in agricultural products and produced them for personal use, while the remaining 59.5\% used products only for personal needs. When asked whether they could make a decent livelihood through agriculture only, $20.6 \%$ of the respondents involved in agriculture (agricultural and mixed households) answered positively; $45.6 \%$ of them answered positively, indicating that agriculture alone could not ensure a decent livelihood; while $33.8 \%$ gave a negative answer. Among the respondents already involved in farming, $52.9 \%$ saw the future of the area in agricultural produc-

Table 1. Respondents in the Reserve's buffer zone (February 2017)

\begin{tabular}{|l|c|c|c|}
\hline $\begin{array}{l}\text { Settlement in the SRP } \\
\text { Protection Zone }\end{array}$ & $\begin{array}{c}\text { Number of adult inhabitants } \\
\text { (Census 2011) }\end{array}$ & $\begin{array}{c}\text { Number of interviewed } \\
\text { adults }\end{array}$ & $\begin{array}{c}\text { Percentage of surveyed } \\
\text { adults }\end{array}$ \\
\hline Belo Blato & 1092 & 96 & $8.8 \%$ \\
\hline Lukino Selo & 417 & 26 & $6.2 \%$ \\
\hline Total & 1509 & 122 & $8.1 \%$ \\
\hline
\end{tabular}

Source: Statistical Office of the Republic of Serbia, 2014

individuals completed secondary education, $42 \%$ had only primary education, while $8 \%$ had a college or university degree.

Although an intensified emigration of young people, especially toward the countries of the European Union, had been observed over the previous years, $71 \%$ of households surveyed (one questionnaire per household was distributed) reported that no family members had emigrated over the previous 20 years. In $13 \%$ of the surveyed households, one member emigrated, whereas $6 \%$ of the surveyed households had two to five members who emigrated. More than five members emigrated from $10 \%$ of the surveyed households. The highest percentage of respondents (69.7\%) saw their future in their current place of residence. In terms of age, the share of those who wanted to emigrate was higher $(66.7 \%)$ only in the category of young people up to 24 years of age. In terms of sex structure, $70.3 \%$ of men and $69 \%$ of women saw their fu- tion. Asked for an opinion on organic farming, 41.9\% found it to be popular. Nevertheless, it is encouraging that a large number of women, who are, as a rule, the main bearers of organic production, saw the future in this industry; they stated that they would undertake this type of production if grants were provided by the state (60.3\% of the surveyed women).

Only $11.5 \%$ of the surveyed population in the protection zone dealt with some type of tourism (renting rooms and houses, catering, souvenirs). Only 7.1\% of them had been involved in tourism before the area was protected, while the others (92.9\%) undertook tourism activities only after protection was declared. When asked whether tourism could ensure a decent livelihood, $85.7 \%$ of the respondents said that it was possible to earn a decent livelihood "but not only from tourism", while $14.3 \%$ responded negatively. However, $78.6 \%$ of the respondents stated that the future of their village could be ensured through rural tourism. The 
largest number of the respondents (42\%) believed that the number of tourists had increased compared to the period prior to protecting the area and considered it to be a direct consequence of the protection procedure. A significant share of the respondents (31\%) observed an increase in the number of tourists, but they did not consider it a consequence of declaring the protection status of the area.

The vast majority of the respondents, accounting for $95.9 \%$, were aware that they were living in a protected area. The highest percentage $(89 \%)$ of the respondents were also aware of the type of protection. A considerable percentage of the respondents (54\%) did not know who the Manager was. The percentage of those who thought that the Manager did not care about the local population was almost the same (49\%); $23 \%$ believed that that the Manager was equally concerned about nature and the population; $20 \%$ considered that the Manager cared more about nature, while $8 \%$ said they did not know anything about it.

The highest percentage of the respondents $(35 \%)$ believed that the act of declaring the protected area had no impact on their lives, either positive or negative (Fig. 2).

No benefit from the life in a protected area was observed by $43.4 \%$ of the local respondents ( 53 surveyed). About $20.5 \%$ of them (25 surveyed) indicated healthy air as a benefit, and $17.2 \%$ (21 surveyed) mentioned an increased number of tourists visiting their area. The others mentioned benefits such as the chance to trade in local products, healthy child upbringing and a having wonderful place for leisure (Fig. 3).

Likewise, the largest number of the respondents ( 48 or $39.3 \%$ surveyed) considered that they did not suffer any damage due to living in a protected area. The respondents who suffered some kind of damage most-

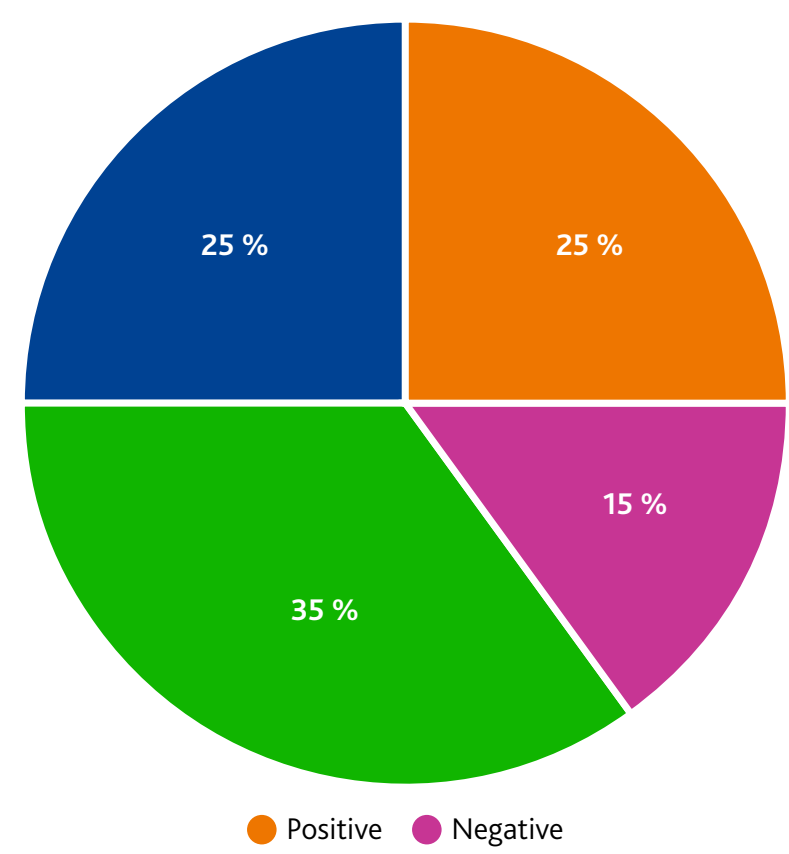

Neither positive nor negative Both positive or negative

Figure 2. The impact of the area protection on the everyday life of the local population

ly complained about the outbreak of wild animals $(25$ surveyed or $20.5 \%$ ), incursions of wild animals and flooding (18 surveyed or $14.7 \%$ ) and the fact that hunting and fishing were banned (12 surveyed or 9.8\%). A number of respondents also mentioned mosquitoes as a disturbing factor (Fig. 4).

Asked to give an overall opinion on the quality of their lives before and after declaring area protection, only $3.3 \%$ claimed that their life quality was better after declaring protection and that it was a result of assigning the protected status to the area. The share of those who said that they lived better than 20

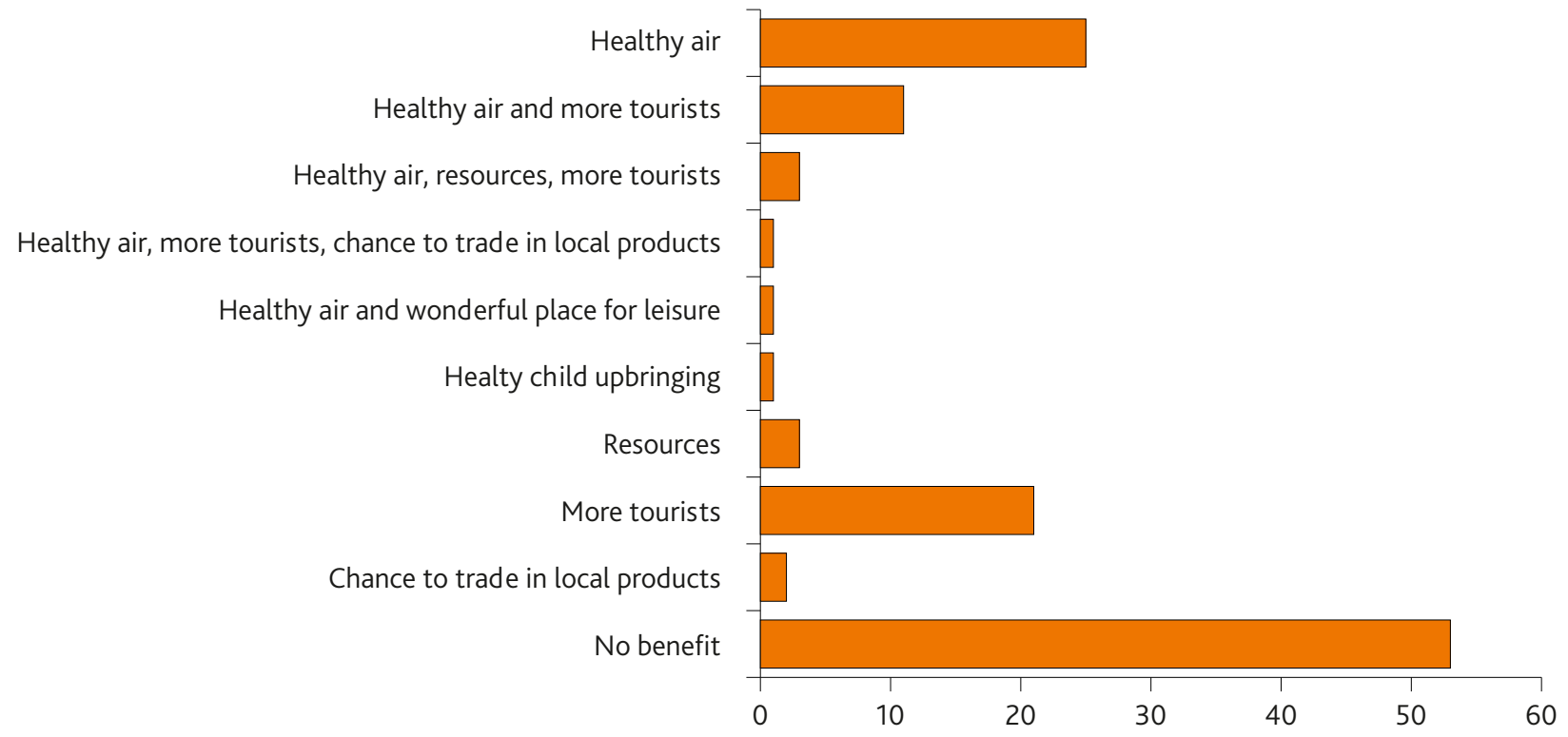

Figure 3. Benefits from living in a protected area 


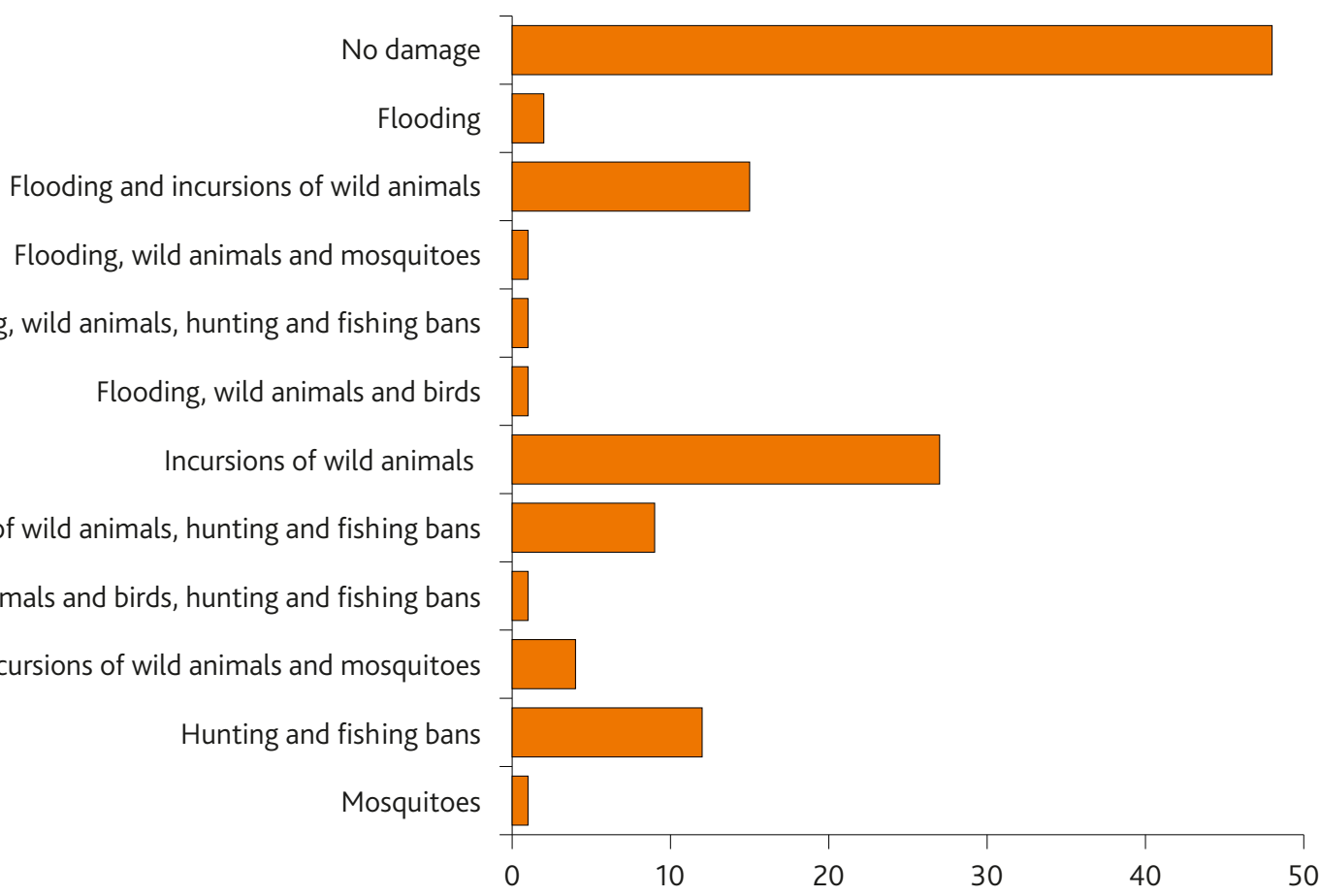

Figure 4. Damages associated with living in a protected area

years before, but not due to the area's protected status was $30.6 \%$, while the largest share of the respondents $(61.2 \%)$ claimed that their life quality was worse, though not as a result of the area's protected status, but due to the overall situation in the country.

Almost all of the respondents (93\%) in the buffer zone considered that the Reserve and its natural values should be preserved. The remaining $7 \%$ advocated for draining the pond and converting it into agricultural land. All of them were farmers who had to deal with incursions of wild animals and who had long been unable to reach an agreement with the Manager.

\section{The area of the Special Nature Reserve's close environment}

The close environment of the Reserve includes the following villages: Knićanin, Perlez and Stajićevo. Knićanin has an unfavorable position in the flood plain of the Tisa and Begej rivers, as embankments are the only protection against high waters. It is the farthest village from the municipal center $(33 \mathrm{~km})$, but only 3 $\mathrm{km}$ away from the town of Titel, South Bačka District.
It is also located along the road which connects Zrenjanin and Novi Sad, the capital of the Vojvodina Province. Stajićevo and Perlez were built on a diluvial (loess) terrace and they have good agricultural land, as opposed to the settlements at the inundation level, where wetland was sometimes used for fishponds (Ćurčić 2004). They have excellent traffic connections. Stajićevo is located by the national road Belgrade-Zrenjanin, whereas Perlez is located at the intersection of the roads connecting Zrenjanin, Novi Sad and Belgrade.

In the three villages located in the close environment of the Reserve, 271 inhabitants were surveyed (Table 2). The average age of the respondents was 38.4 years. The surveyed sample consisted of $31.7 \%$ of men and $68.3 \%$ of women. The largest share of the respondents $(69 \%)$ had a secondary education, $19.6 \%$ had elementary education, $11.1 \%$ had a college or university degree, and $0.4 \%$ had no education.

Of the total number of the respondents involved in agriculture (53.1\%), $34.7 \%$ personally used and sold their products, while the other $65.3 \%$ used agricultural products solely for personal needs.

Table 2. Respondents in the close environment of the Reserve (February 2017)

\begin{tabular}{|l|c|c|c|}
\hline $\begin{array}{l}\text { Settlement in the SRP } \\
\text { Protection Zone }\end{array}$ & $\begin{array}{c}\text { Number of adult inhabitants } \\
\text { (Census 2011) }\end{array}$ & $\begin{array}{c}\text { Number of interviewed } \\
\text { adults }\end{array}$ & $\begin{array}{c}\text { Percentage of the surveyed } \\
\text { adults }\end{array}$ \\
\hline Knićanin & 1472 & 64 & $4.4 \%$ \\
\hline Perlez & 2794 & 117 & $4.2 \%$ \\
\hline Stajićevo & 1570 & 90 & $5.7 \%$ \\
\hline Total & 5836 & 271 & $4.6 \%$ \\
\hline
\end{tabular}

Source: Statistical Office of the Republic of Serbia, 2014 
In $86.4 \%$ of the households surveyed (one questionnaire per household was distributed), no members had emigrated in the previous 20 years. One member per household emigrated from $7.3 \%$ of the surveyed households, two to five members emigrated from $5 \%$, and more than five members from $1.3 \%$ of the surveyed households. The highest percentage of the respondents (69.7\%) saw a future in their current place of residence. In terms of sex structure, $67.4 \%$ of men and $69.2 \%$ of women saw their future in their place of living. As far as the education level is concerned, the preference for staying in their village was common among the respondents with the lowest level of education (elementary school), who accounted for $81.1 \%$. The inhabitants with a secondary or grammarschool education who wished to stay in the village, accounted for $66.8 \%$; this answer was chosen by $56.7 \%$ of those with a college or university degree.

Most respondents used land as the only resource, $62 \%$ of them, but these were mainly gardens cultivated for personal needs. Gardens were located in their home yards, with vegetables, fruits and, prevailingly, flowers. Inhabitants who owned many acres of land and who were more seriously involved in agriculture were generally rare. Along with gardening $5.6 \%$ of the respondents were also involved in hunting and fishing, $2.6 \%$ only in hunting and fishing, while the remaining $29.8 \%$ of the respondents said they did not use any resources whatsoever. When asked if they could make a decent livelihood from agriculture only, $24.4 \%$ of the respondents involved in agriculture (agricultural and mixed households) gave a negative answer, while $57.3 \%$ answered positively, though indicating that they could not make a decent living from agriculture only. Among the respondents already involved in farming, $65.6 \%$ believed that the future of the area lied in agricultural production. When asked for an opinion on organic farming, 51.9\% of the total respondents claimed that it was popular. Most women covered by the survey shared this opinion $(53.6 \%$ of the surveyed women). The future of such a valuable part of nature could really be in organic production and agrotourism. But in Serbia, organic production has not yet reached the scale comparable to Western countries. The area under organic production in 2015 was only $0.5 \%$ or 15,298.01 ha (Krunić-Lazić et al., 2017).

Only $1.1 \%$ of the respondents in the close environment of the Reserve were involved in some kind of tourism. Out of the total number of the respondents who said they were not involved in tourism, $97.8 \%$ had never been involved in tourism, and $1.5 \%$ had been involved in this industry previously, but not at the time of the survey. Out of the remaining $0.7 \%$ of those who were involved in tourism, one-half worked in this industry before establishing the protected area, and another half were active in the industry over the several years pre- ceding the survey. Only $15 \%$ of respondents considered that the number of tourists had increased, compared to the period before the protected area was established and considered it to be a direct consequence of the procedure. A low percentage of the respondents $(6 \%)$ observed an increase in the number of tourists but did not consider it a consequence of declaring the protected status. The respondents who considered that the Reserve and its environment attracted the same number of visitors as 20 years before (when the protection was first established) accounted for $38 \%$ of the total respondents, while $41 \%$ thought that the number of tourists was than 20 years before. Based on the results of the survey, as well as on interviews with local inhabitants, it was easy to conclude that the only visitors were those who came to visit their relatives, usually during summer. In all of the three villages, many respondents claimed that tourists never visited their villages. When asked if tourism could provide a decent income for them, 33.3\% thought that it could, while the remaining $66.7 \%$ answered "Yes, but not only tourism". When asked if they saw the future of their village in tourism, $33.3 \%$ answered positively and $66.7 \%$ negatively.

The majority of the respondents ( $75.6 \%)$ were aware that they were living close to the protected area. The largest share of the respondents (71\%) knew which type of protected area it was, although the share of those who did not know this information was not negligible (26\%). Only $3 \%$ thought it was National Park. As many as $88 \%$ of the respondents did not know who the Manager was. Most respondents considered that the Manager did not care about the local population

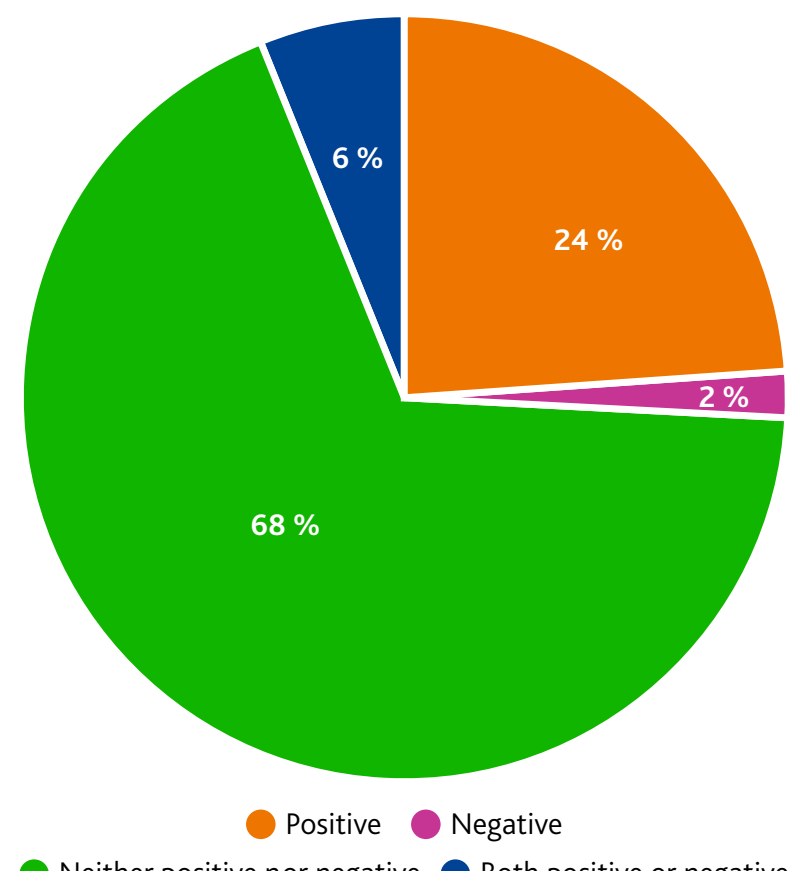

Neither positive nor negative Both positive or negative

Figure 5. The impact of the Reserve on the everyday life of the local population 


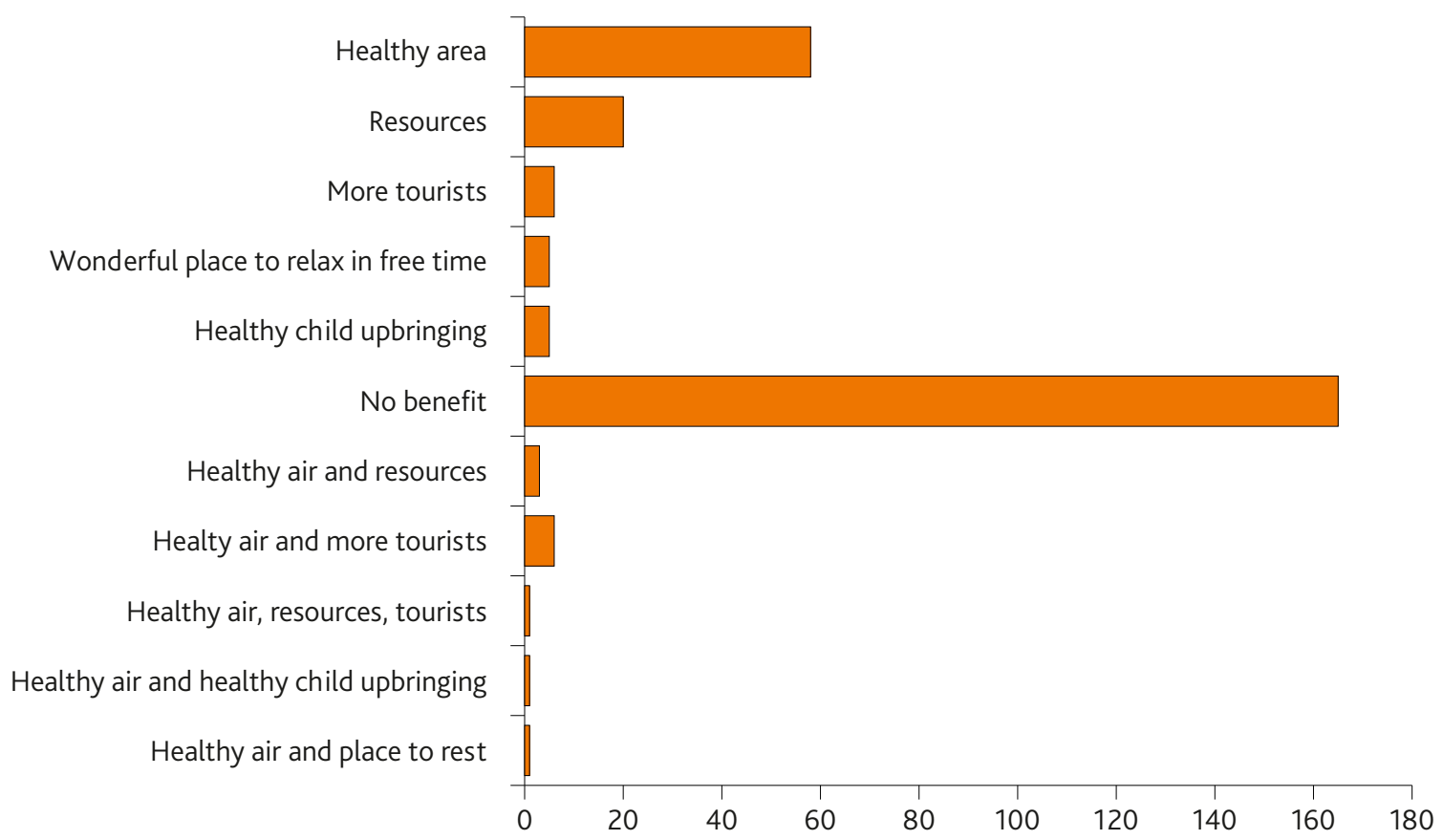

Figure 6. Benefits of living in a protected area

at all $-41 \% ; 29 \%$ of the respondents believed that the Manager was equally concerned about nature and inhabitants, $19 \%$ thought that the Manager took more care of nature, while $11 \%$ of the respondents did not want to share their attitude.

Most respondents (68\%) believed that the area protection had no impact on their everyday life either positively or negatively (Fig. 5).

Also, most respondents did not recognize the benefits of living in the close environment of the Reserve. As many as $60.9 \%$ of the respondents (165 surveyed) saw no benefit of living close to the protected area. Ecosystem services, such as supply services (healthy air, clean water, resources) or cultural services (a healthy environment for everyday rest and upbringing of children, a place for recreation, beautiful landscapes), were not recognized by residents as a value (Fig. 6).

The number of the respondents who complained of the damage arising from the rules of nature protection and the use of land defined in the Regulation was

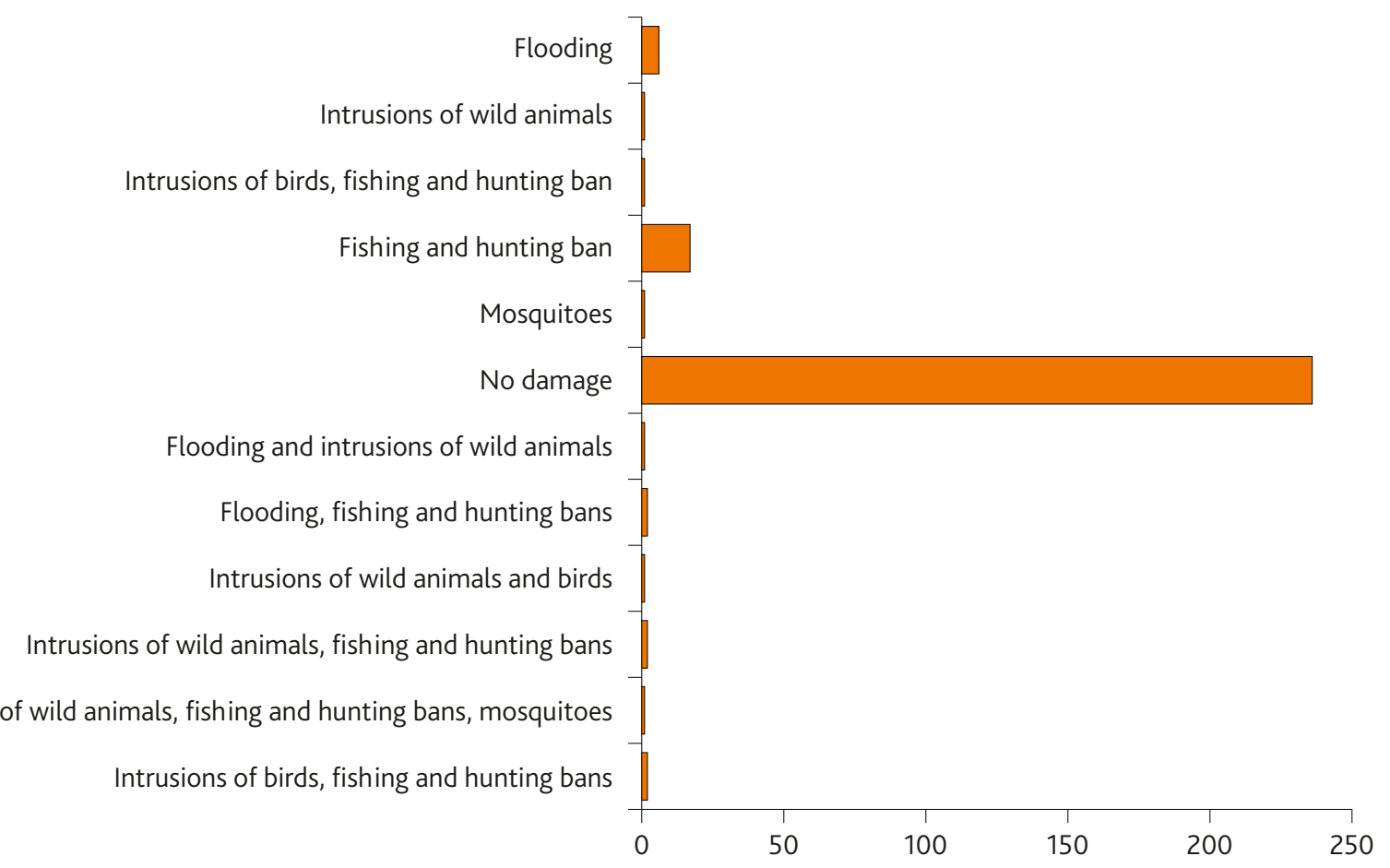

Figure 7. Damage associated with living in a protected area 
smaller than, as opposed to the number of those in the buffer zone. Namely, $87.1 \%$ of the inhabitants of the three settlements in the close environment of the Reserve (236 surveyed) stated that they did not suffer any damage. The rest complained about hunting and fishing bans, flooding, damage caused by intrusions of birds and wild animals, and the inability to apply mosquito suppression measures (Fig. 7).

Asked to give an overall opinion on the quality of living before and after establishing the protected area, only $1.9 \%$ of the respondents said that it was better at the time of the survey, as a result of declaring the protected status; $28.5 \%$ of the respondents claimed that they were living better than 20 years before, though not due to the area protection, while the majority of the respondents (69.3\%) said that they lived worse at the time of the survey, though not as a result of the protected status of the area, but due to the situation in the country.

Unlike inhabitants in the buffer zone, all respondents from the close environment of the Reserve believed, without exception, that the Reserve and its natural values should be preserved.

\section{The Manager's attitudes}

Some of the questions (eight of them) presented to the inhabitants were also presented to the Manager -the Ečka Fishing Farm. The Manager's attitudes differed significantly from the attitudes of the locals, revealing that the real dialogue between these two stakeholders had not yet been established. There was evidently misunderstanding on both sides. For example, we will mention only the case of mosquitoes, often referred to by the locals as a harmful effect of the area's protected status. According to them, the Manager did not suppress mosquitoes because of nature protection measures. However, during the interview, the representative of the Manager dealing with environmental issues (the Representative), provided evidence that the suppression of mosquitoes had been performed in the previous, rather long period. Other, similar examples could be cited, but in many cases, it was impossible to determine which side had right. The Representative of the manager claimed that local residents knew very well which parts of the Reserve were covered by the protection regime, where they could or could not fish, cut reed, etc. The Representative cited the bridge on the route to Belo Blato as an example: the middle of the bridge marked the boundary of the Reserve and it was possible to see locals fishing on one side of the bridge and a ranger standing on the other, unable to take any legal action. The Representative confirmed the persisting dispute with farmers from Belo Blato regarding the compensation for incursions of wild animals. Although according to the law the Manager was not obliged to compensate them for the damage done (it was the responsibility of the State) they usually demanded compensation from the Manager. The Manager believed that they did so because they were familiar with the practice of their neighbors from Romania and Hungary, with whom they had regular contacts since a large number of national minorities lived in the investigated area. According to the Representative, they were not aware that the countries mentioned were EU members and part of the Natura20oo network, due to which they were subject to different rules.

Establishing closer cooperation between local community and manager is not that simple, because Serbia has "a long history of centralized approaches to planning and management in protected areas" (Tomićević et al., 2010). Also, what should always be kept in mind is the necessity of a comprehensive analysis of each rural area, due to the fact that it is not just an area for the production of goods, but also the habitation of people of a certain cultural identity and mutual social relations (Auer et al., 2017).

The analysis of the responses provided by the Representative showed the following: the Manager believed that living in the buffer zone or in the close vicinity of the Reserve had only a positive impact on the local population, since tourists who visited the Reserve paid visits to some of the surrounding villages (specifically, Belo Blato), which they would not otherwise visit. The local residents had an opportunity to sell their products and they had access to a beautiful nature and a recreation spot in their vicinity. The Representative considered that they suffered no damage, but when asked about the compensation for the damage, the Representative replied that no compensations were provided to the locals because they failed to comply with relevant legal procedures or establish a committee at the local government level. Finally, the Representative admitted that the Manager was more committed to nature protection than the interests of the local population. 


\section{Conclusion}

All of the presented results, supported by interviews with the local population and the Representative, as well as the insight into the on-site situation, lead to the following conclusions regarding the sub-hypotheses tested in this study.

The benefits from living near the Reserve were not recognized by $43.4 \%$ of the surveyed residents in the buffer zone and $60.9 \%$ of those surveyed in the villages in the Reserve's close environment. The rest of the respondents were aware of the benefits, such as healthy air, tourists who would not otherwise visit their villages and an environment suitable for relaxing and healthy child upbringing. Sub-hypothesis Hia was proven to be false for the villages in the buffer zone of the Reserve, while in the case of villages in the close environment of the Reserve it was found to be true.

The residents who reported no damage caused by living near the Reserve accounted for $39.3 \%$ of the surveyed population in the villages of the buffer zone and $87.1 \%$ of those surveyed in the villages in the Reserve's close environment. The remaining respondents complained of the incursions of wild animals and birds, flooding, fishing bans and mosquitoes. Sub-hypothesis $\mathrm{H} 1 \mathrm{~b}$ was proven to be false for the villages within the protection zone, while in the case of villages in the close surroundings of the Reserve, it was found to be true.

Most respondents answered positively when asked whether they planned to stay in their village. It was only among young people, between 18 and 24 years of age, in both parts of the investigated area, that most respondents preferred to leave their current place of residence. Sub-hypothesis Hic was proven to be true.

As far as the education level is concerned, in all categories of the respondents, the preference for staying in the current place of residence was the prevailing attitude. In the close environment of the Reserve, the respondents who preferred to stay in their place of residence made a vast majority of the residents with the lowest education level (elementary school). In all other categories of respondents (according to education level) the preference for staying in the current place of residence prevailed, though the percentages were smaller. Sub-hypothesis Hid turned out to be false.

Based on the presented findings, it can be concluded that Sub-hypothesis Hie, regarding the impact of the location, i.e. the village's proximity to the Reserve, is true. The most illustrative evidence of this is the example of farmers from Belo Blato, whose fields bordered on the Reserve and who were the only ones who believed that the Pond should be drained.

The conclusion is that the basic $\mathrm{H}_{1}$ hypothesis is false. In some aspects, and depending on the location, the establishment of the Reserve has had an impact on the life and economy of the local population.

Most respondents were aware that they lived near the protected area (95.9\% in the buffer zone and $75.6 \%$ in the close environment), and many of them were also aware of the protection type. This awareness was especially present among the residents of the buffer zone (89\%), while the respondents living in remote settlements were less likely to know the protection type (71\%).

The respondents generally had a negative attitude towards the Manager. The majority of the respondents claimed that they did not know who the Manager was ( $54 \%$ in the buffer zone and as many as $88 \%$ in the close environment), and almost half of them stated that the Manager did not care about them at all. There was a general misunderstanding between the parties. The local population did not pay fishing licenses. This obligation had been put in place already before establishing the protected area but it had not been respected because there had been no control, while after the establishment of the Reserve rangers were appointed. The locals complained that the Manager did not suppress mosquitoes due to nature protection measures, though in fact mosquitoes were regularly suppressed by appointed ecological agents. A proper relationship between these stakeholders is yet to be established.

If a rural environment is surrounded, such as this, with the richness and diversity of natural resources, and is also under a protected status, the development of ecotourism and agrotourism as a form of rural tourism can be an important way to increase the income of a household. More than one-half of the respondents, equally in the buffer zone and the Reserve's close environment, see the future of the investigated area in agricultural production. The economic incentives provided by the government for organic production are still on a small scale (0.4\% of the total national budget was allocated for the environment, SEPA, 2015 - http://www.sepa.gov.rs/download/SEPA_ECOEXPO_2015.pdf). There is no market for organic products, as they are expensive to the majority of the population, and potential producers are burdened with large initial investments. Furthermore, the awareness of farmers and the rural population in general, about the importance of transition to organic production is still insufficiently developed. The development of tourism requires great initial investment. At the same time, both require labor, and the population has been persistently declining, especially in rural areas. According to the latest census (2011) the studied area had 644 inhabitants less than at the 
time of the previous census (2002) and 1653 inhabitants less than in 1991 (Statistical office of the Republic of Serbia, 2014).

However, when tourism and the future are concerned, the attitudes of the respondents from these two zones differ significantly. While the majority of inhabitants in the buffer zone see the future of their region in tourism, the inhabitants of the Reserve's close surroundings do not consider it as a prospective future. Indeed, Belo Blato is the only among the explored villages to be developing tourism, though very slowly. Other villages do not have resources for this.

The Carska Bara Special Nature Reserve is primarily attractive to excursionists because of its rare and attractive nature. However, the studied area also has a significant cultural potential, which is not yet fully used and is not even shaped into a tourist product. An insight into the on-site situation and an analysis of literature and internet portals dealing with the local cultural offer lead to the conclusion that the solution lies in a unified tourist offer (natural and anthropogenic motifs), as the cultural motifs of this area alone cannot attract a large number of tourists.

The area in which the Reserve is located is wellconnected. Along the southeastern boundary of the Reserve runs the first-class national road (Zrenjanin-Belgrade), and the main dispersive tourist attractions are the cities of Zrenjanin (16 km), Novi Sad (50 $\mathrm{km})$ and Belgrade $(52 \mathrm{~km})$. The available accommodation capacities are sufficient (hotels Sibila and Kaštel, ethno-houses, guesthouses). The main disadvantage of the investigated area is the lack of a young, work- ing and reproductive population, because young people keep on leaving the area. Another problem is the lack of the Manager's initiative to establish a more efficient dialogue and cooperation among the parties and a purposeful utilization of resources, eventually attracting a new population in a process that is increasingly common in the countries of Western Europe and is referred to in the literature as naturbanization - urbanization of protected and highly valued natural spaces, a variant of the deurbanization or counterurbanization process (Prados, 2005; Palarès-Blanch, 2012; Palarès-Blanch et al., 2015).

The Reserve, with its numerous natural resources, provides excellent opportunities for development of this area. Lack of cooperation between the Manager and local population presents great obstacle on that path. It is necessary to unite them in cooperation towards accomplishment of common goal - development of the area and making of profit. Tourism may connect them on that path. Fishing tourism, above all, having in mind the main activity of the Manager and the fact that responders emphasized quality of life when Lake Joca operated in full capacity (while privately leased, anyway). Through development of tourism the agriculture would re-alive by provision of healthy domestic organic food for the visitors. Local population would find its interests there. The local associations of women with theirs products and handiworks as native souvenirs would also join. United approach to marketing, primarily by web-site (the Manager's web-site is scarce and outdated), is also welcome.

\section{Acknowledgements}

We would like to express our gratitude to all the interviewees in five villages of the researched area, for their time and hospitality. Also to the Representative of the Ečka Fishing Farm, who helped with exhaustive conversations and all the necessary material. The work is a part of the project 47007 III funded by the Ministry of Education, Science and Technological Development of the Republic of Serbia.

\section{References}

Auer, A., Maceira, N., \& Nahuelhual, L. (2017). Agriculturisation and trade-offs between commodity production and cultural ecosystem services: A case study in Balcarce County. Journal of Rural Studies, 53, 88-101. doi:10.1016/j.jrurstud.2017.05.013

Bennett, N.J., \& Dearden, P. (2014). Why local people do not support conservation: Community perceptions of marine protected area livelihood impacts, governance and management in Thailand. Marine Policy, 44, 107-116. https://doi.org/10.1016/j.marpol.2013.08.017.
Christopoulou, O.G., \& Tsachalidis, E. (2004). Conservation Policies for Protected Areas (Wetlands) in Greece: A Survey of Local Residents' Attitude. Water, Air, and Soil Pollution: Focus, 4(4/5), 445-457. doi:10.1023/b:wafo.00ooo44817.88422.64

Drašković, B. (2013). Resource management of protected areas in Serbia: Special nature reserves of Zasavica, Uvac, Stari Begej and Carska bara. (p. 362). Belgrade: Belgrade banking academy - Faculty of banking, insurance and finance - Institute of Economic Sciences. (in Serbian). 
Ćurčić, S. (2004). Banat settlements: Geographical characteristics. In Monograph of Fruška gora. (p. 397). Novi Sad: Matica srpska - Departmant of Natural Sciences. (in Serbian).

Ministry of environmental protection and Institute for nature conservation of Serbia. (2007). Protected natural assets of Serbia. (p. 260). Belgrade. (in Serbian and English - bilingual).

Thapa, K.S. (2013). Do protected areas and conservation incentives contribute to sustainable livelihoods? A case study of Bardia National Park, Nepal. Journal of Environmental Management, 128, 988-999. doi:10.1016/j.jenvman.2013.06.054

Krunić-Lazić, M., Vidojević, D., \& Popović, S. (2017). Economic potentials and activities of importance for the environment in the Republic of Serbia for 2015 - Indicator presentation. (p. 36). Belgrade: Ministry of agriculture and environment - Environmental protection agency. (in Serbian).

Ministry of Environmental Protection of Republic of Serbia. (2011). Decree on Proclamation of Special nature Reserve "Carska bara". Official gazette of the Republic of Serbia, 46, (in Serbian).

Spatial Plan for the special purpose Area Stari Begej: Carska bara. Official journal of the Province of Vojvodina, (2009). No 8.

Pallares-Blanch, M. (2012). Natural Protected Areas and Rural/Local Development: A Sustainable Strategy in Remote Areas. Urbani izziv, 23(s 2), 87-96. doi:10.5379/ urbani-izziv-en-2012-23-supplement-2-007

Pallarès-Blanch, M., Tulla, A.F., \& Vera, A. (2015). Environment Capital and Women's Enterpreneuership: A Sustainable Local Development Approach. Carpathian Journal of Earth and Environmental Sciences, 10(3), 133-146. Available at: http://www.ubm.ro/ sites/CJEES/viewTopic.php?topicId=556.

Pavić, D., Jakovljević, D., \& Krajić, A. (2016). Local Reactions Concerning Serbia's Obedska Bara Nature Reserve. Polish Journal of Environmental Studies, 25(1), 273-282. doi:10.15244/pjoes/60501
Petrovic, M., Gelbman, A., Demirovic, D., Gagic, S., \& Vukovic, D. (2017). The examination of the residents' activities and dedication to the local community an agritourism access to the subject. Journal of the Geographical Institute Jovan Cvijic, SASA, 67(1), 3752. doi:10.2298/ijgi1701037p

Prados, M. (2005). Territorial Recognition and Control of Changes in Dynamic Rural Areas: Analysis of the Naturbanization Process in Andalusia, Spain. Journal of Environmental Planning and Management, 48(1), 65-83. doi:10.1080/0964056042000308157

Statistical office of the Republic of Serbia. (2014). Census of population, households and dwellings in the Republic of Serbia 2011. Comparative overview of the number of population in 1948. 1953. 1961. 1971. 1981. 1991. 2002 and 2011. Data by settlements. book 20. Belgrade, Serbia.

Stojanović, V., Lazić, L., Pavić, D., Panjković, B., Košić, K., Dragin, A., Stankov, U., Jovanović, M., Pantelić, M., Stamenković, I., Ivanović, Lj. (2011). Feasibility study of the development of ecotourism in the protected natural resources of Vojvodina (with special reference to Ramsar sites). (p. 192). Novi Sad: University of Novi Sad - Faculty of Sciences - Department of Geography, Tourism and Hotel Management. (in Serbian).

Sznajder, M., Przezborska, L., \& Scrimgeour, F. (2009). Agritourism. Wallingford: CABI Publishing. doi:10.1079/9781845934828.00oo

Tomićević, J., Shannon, M.A., \& Milovanović, M. (2010). Socio-economic impacts on the attitudes towards conservation of natural resources: Case study from Serbia. Forest Policy and Economics, 12(3), 157162. doi:10.1016/j.forpol.2009.09.006

Wood, M.E. (2002). Ecotourism. Principles, practices and policies for sustainability. (p. 32). Belgrade: United Nations Environment Program - The International Ecotourism Society - Center for Responsible and Sustainable Tourism Development. (in Serbian). 